\title{
Protective Effect of Whole and Fat-Free Fluoridated Milk, Applied before or after Acid Challenge, against Dental Erosion
}

\author{
Luiza P.S. Cassiano $^{a}$ Senda Charone ${ }^{a} \quad$ Juliana G. Souza ${ }^{a} \quad$ Ligia C. Leizico $^{a}$ \\ Juliano P. Pessan ${ }^{b}$ Ana Carolina Magalhães ${ }^{a}$ Marília Afonso Rabelo Buzalafa \\ aDepartment of Biological Sciences, Bauru School of Dentistry, University of São Paulo, Bauru, and \\ ${ }^{\mathrm{b}}$ Araçatuba Dental School, Universidade Estadual Paulista (UNESP), Araçatuba, Brazil
}

\section{Key Words}

Dentine $\cdot$ Enamel $\cdot$ Fluoride $\cdot$ Milk · Tooth Erosion

\begin{abstract}
This study analysed in vitro the effect of milk against dental erosion, considering three factors: the type of milk (bovine whole/fat-free), the presence of different fluoride concentrations and the time of application (before/after erosive challenge). Bovine enamel ( $n=15 /$ group) and root dentine $(n=$ 12 /group) specimens were submitted to the following treatments: after the first erosive challenge $-0.9 \% \mathrm{NaCl}$ solution (negative control), whole milk with 0, 2.5, 5.0 and 10.0 ppm F, fat-free milk with 0, 2.5, 5.0 and 10.0 ppm F, and $0.05 \%$ $\mathrm{NaF}$ solution (positive control); before the first erosive challenge - whole milk with 0, 2.5, 5.0 and 10.0 ppm F, fat-free milk with 0, 2.5, 5.0 and 10.0 ppm F, and $0.05 \%$ NaF solution (positive control). Specimens were submitted to demineralisation-remineralisation regimes 4 times/day for 5 days. The response variables were enamel and dentine loss (in micrometres). Data were analysed using Kruskal-Wallis/Dunn's test ( $p<0.05$ ). For enamel, whole milk containing 10 ppm F, applied before the erosive challenge, was the most protective treatment, but with no significant difference compared with the same treatment carried out after the erosive chal-
\end{abstract}

lenge. For dentine, whole fluoridated milk (all concentrations, after), fat-free 10 ppm F milk (after, before) and whole milk with or without F (except 2.5 ppm F, all before) significantly reduced dentine erosion. It seems that the presence of fluoride, especially at $10 \mathrm{ppm}$, is the most important factor in reducing dental erosion.

(c) 2016 S. Karger AG, Basel

Saliva, the most potent biological factor modulating tooth erosion, can provide calcium, phosphate and fluoride ions for remineralisation. It is also able to dilute and neutralise the acids and provides proteins that form the acquired pellicle, which impairs the contact between the acid and the tooth surface [Buzalaf et al., 2012]. When a 2-hour pellicle was formed in situ on enamel, it reduced erosion 2-fold more than when it was formed on dentine, regardless of the type of acid (hydrochloric, citric or phosphoric acid) [Wiegand et al., 2008]. This result may be explained by the fact that dentine erosion histologically progresses in a different way compared with enamel erosion due to the presence of a demineralised collagen layer, which might have a different interaction with salivary proteins [Ganss et al., 2004].

\section{KARGER}

E-Mail karger@karger.com

www.karger.com/cre
(C) 2016 S. Karger AG, Basel

0008-6568/16/0502-0111\$39.50/0
Marília Afonso Rabelo Buzalaf

Department of Biological Sciences, Bauru School of Dentistry

University of São Paulo, Al. Octávio Pinheiro Brisolla, 9-75

Bauru, SP 17012-901 (Brazil)

E-Mail mbuzalaf@fob.usp.br 
The effect of saliva can be increased by the presence of foods containing high amounts of calcium and phosphate [Gedalia et al., 1991a, b], such as milk, a beverage rich in components such as minerals, proteins and lipids, which has been extensively studied to protect against demineralisation [Rugg-Gunn, 1993; Aimutis, 2004; Merritt et al., 2006]. Furthermore, milk fat and protein may adhere to the tooth surface covered by the acquired pellicle, acting as a protective barrier against dietary or intrinsic acids. Thus, theoretically, it seems plausible that milk can protect against erosion. Despite the fact that some clinical studies have shown a protective effect of milk consumption on the reduction of erosion prevalence [Nahas Pires Correa et al., 2011; Manaf et al., 2012; Salas et al., 2015], a meta-analysis evaluating the dietary factors associated with tooth erosion found no relationship between milk consumption and dental erosion [Li et al., 2012].

To increase the protective potential of milk, fluoride was added and recently investigated against tooth erosion in vitro [Magalhães et al., 2014]. In this study, whole milk containing $\mathrm{F}$ (ranging between 2.5 and $10.0 \mathrm{ppm}$ ) was able to significantly reduce enamel and dentine erosion compared with whole non-F milk, but no dose-response was observed. Moreover, whole non-F milk applied before the first erosive challenge showed a more protective effect than whole non-F milk applied after the erosive challenge. We speculated that the milk fat was deposited on the tooth surface, forming a protective layer that was able to reduce the contact between the acid and the tooth. Therefore, it would be interesting to compare whole milk with fat-free milk to confirm this hypothesis, considering also the presence of $\mathrm{F}$ or not and the time of application, as well as the possible interactions among these factors. Therefore, the aim of this study was to analyse the protective effect of milk against enamel and dentine erosion in vitro, considering three factors: (1) the type of milk (bovine whole vs. fat-free), (2) the presence of different $\mathrm{F}$ concentrations $(0,2.5,5$ and $10 \mathrm{ppm} \mathrm{F})$ and (3) the time of application (before vs. after erosive challenge). The null hypothesis was that these three factors would not interfere in enamel and dentine erosion.

\section{Materials and Methods}

\section{Specimen Preparation}

Bovine permanent incisors recently extracted (caries free) were disinfected and kept in $0.1 \%$ buffered thymol solution ( $\mathrm{pH} 7.0$ ) at room temperature for at least 30 days and submitted to visual analysis for the investigation of possible stains and cracks. If these alterations were detected, the teeth were excluded.
The selected teeth were carefully cleaned from gingival tissue using a periodontal curette (Duflex, Brazil) before being cut. The crowns were separated from the roots using a precision cutting machine (ISOMET low-speed saw; Buehler, USA) and a diamond disc (double-sided XL 12205 'high concentration', $102 \times 12.7 \times 0.3$ $\mathrm{mm}^{3}$; Extec Corp., USA). The crowns and roots were then embedded separately in acrylic resin plates (JET, Brazil). The enamel and dentine surfaces were ground flat with water-cooled carborundum discs $\left(320,600\right.$ and 1,200 grades of $\mathrm{Al}_{2} \mathrm{O}_{3}$ paper; Buehler) and polished with felt paper wet by diamond spray (grade of $1 \mu \mathrm{m}$; Buehler). After polishing, the specimens were cleaned in an ultrasonic device with deionised water for $5 \mathrm{~min}$.

The reference areas on the polished enamel/dentine surfaces were marked with two parallel lines $1.5 \mathrm{~mm}$ apart made with a scalpel blade. Small drilling was also carried out on one of the control surface areas to allow reproducibility of the profilometric measurements. Baseline scans were obtained as further described. Prior to the experiment, $2 / 3$ of the polished enamel/dentine surfaces were protected with red nail varnish in order to create a control area, leaving only $1 / 3$ of the central area exposed to the erosive challenges.

\section{Fluoride Treatment and pH Cycling Model}

The sample size was calculated based on data from our previous study [Magalhães et al., 2014]. A sample size of 11 and 5 would be needed for enamel and dentine, respectively, in order to find a significant difference between the negative control $(0.9 \% \mathrm{NaCl})$ and milk containing no fluoride, considering an a value of 0.05 and $80 \%$ power. Thus, we decided to include 15 and 12 specimens in each group for enamel and dentine, respectively. The enamel $(\mathrm{n}=$ $285)$ and root dentine $(n=228)$ specimens obtained from bovine incisors as described above were subjected to the following treatments: after the first erosive challenge $-0.9 \% \mathrm{NaCl}$ solution (negative control), whole milk with $0,2.5,5.0$ and $10.0 \mathrm{ppm} \mathrm{F}$, fat-free milk with $0,2.5,5.0$ and $10.0 \mathrm{ppm} F$, and $0.05 \% \mathrm{NaF}$ solution (positive control); before the first erosive challenge - whole milk with 0, 2.5, 5.0 and 10.0 ppm F, fat-free milk with $0,2.5,5.0$ and 10.0 ppm $\mathrm{F}$ and $0.05 \% \mathrm{NaF}$ solution (positive control).

The whole milk presented $3 \mathrm{~g} \%$ total fat, $1.85 \mathrm{~g} \%$ saturated fat and $0 \mathrm{~g} \%$ trans-fat, while fat-free milk presented $0.2 \mathrm{~g} \%$ total fat (Parmalat, Brazil). Fresh fluoridated milk (whole or fat-free milk) was prepared using $\mathrm{NaF}$ for each day of treatment [Malinowski et al., 2012a].

The specimens were submitted to an erosive demineralisation for 5 periods of $24 \mathrm{~h}$ each. They were consecutively cycled through this regime 4 times a day. A complete cycle included the following steps for groups treated after erosive demineralisation: (1) demineralisation in $30 \mathrm{ml}$ of $0.1 \%$ citric acid ( $\mathrm{pH} 2.5$ ) for $90 \mathrm{~s}$; (2) immersion in $30 \mathrm{ml}$ of milk or $\mathrm{NaCl}$ or $\mathrm{NaF}$ solution for $1 \mathrm{~min}$ (only at the first cycle of each day); (3) immersion in $30 \mathrm{ml}$ of 1:1 slurry containing milk:artificial saliva ( $15 \mathrm{ml}$ each, only at the first cycle of each day) for $10 \mathrm{~min}$, and (4) remineralisation in artificial saliva for $50 \mathrm{~min}$ at $25^{\circ} \mathrm{C}$ under agitation. For groups treated before erosive demineralisation, one complete cycle comprised the following steps: (1) immersion in $30 \mathrm{ml}$ of milk or $\mathrm{NaCl}$ or $\mathrm{NaF}$ solution for $1 \mathrm{~min}$ (only at the first cycle of each day); (2) immersion in $30 \mathrm{ml}$ of $1: 1$ slurry containing milk:artificial saliva ( $15 \mathrm{ml}$ each, only at the first cycle of each day) for $10 \mathrm{~min}$; (3) demineralisation in $30 \mathrm{ml}$ of $0.1 \%$ citric acid ( $\mathrm{pH} 2.5$ ) for $90 \mathrm{~s}$, and (4) remineralisation in artificial saliva for $50 \mathrm{~min}$ at $25^{\circ} \mathrm{C}$ under agitation (fig. 1). All specimens were immersed in the respective solutions at the same time, using a customised plastic device. The artificial saliva was prepared according to Klimek et al. [1982]. After 


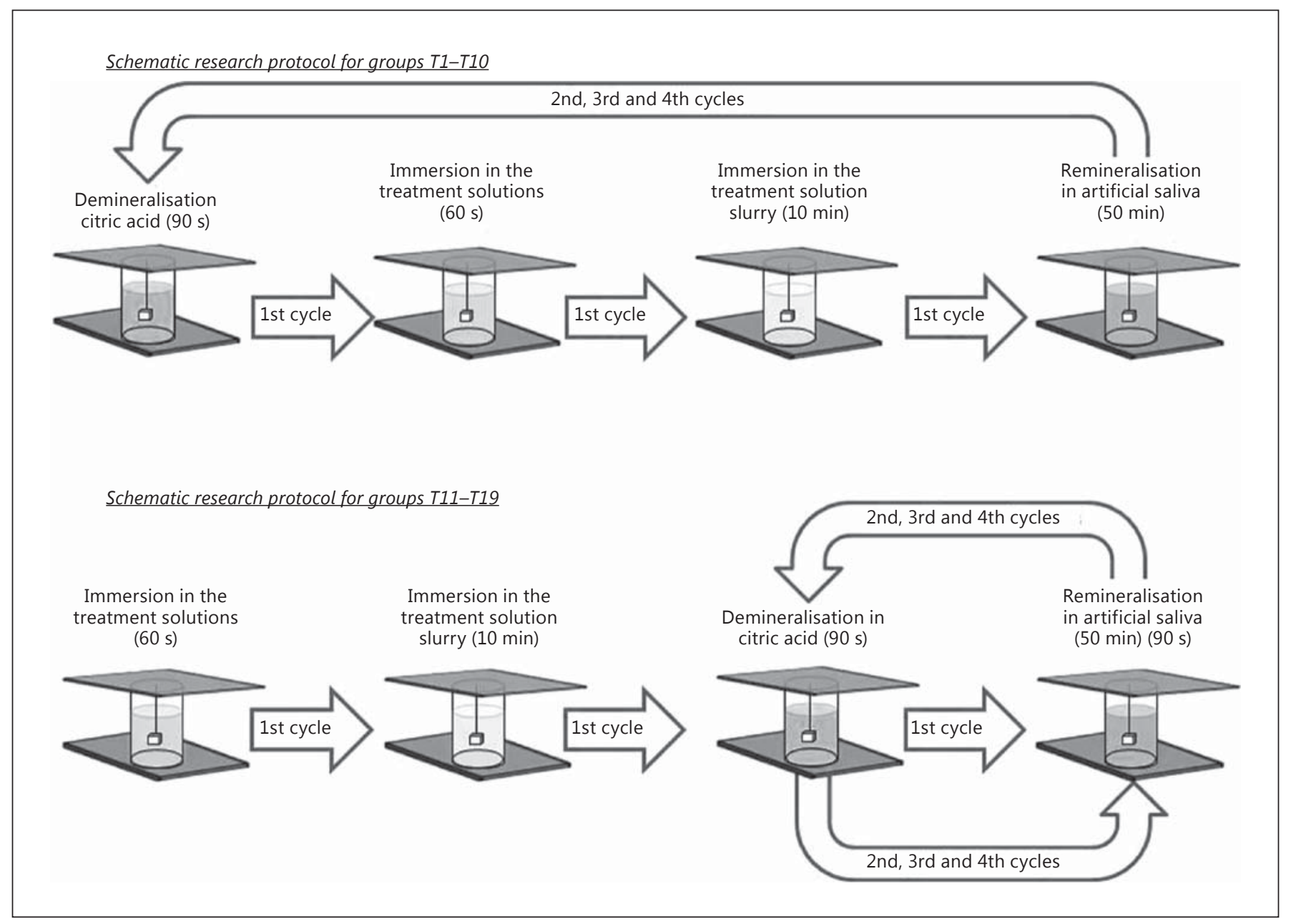

Fig. 1. Experimental design of the study. T1-T10 = Treatments $1-10$. Treatment solution: whole and fat-free milk with $0,2.5,5$ and 10 ppm F; $0.05 \% \mathrm{NaF}$ solution (positive control). Slurry: $15 \mathrm{ml}$ of artificial saliva $+15 \mathrm{ml}$ of treatment solution.

the last cycle of each day, the specimens were stored in artificial saliva. At the end of the experiment, the specimens were stored with moistened gauze until the final profilometric analysis.

\section{Profile Measurement}

Dental erosion was quantified using a contact profilometer (MarSurf GD 25; Göttingen, Germany). At baseline, five equidistant surface scans of each sample were performed (5-mm reading, $250 \mu \mathrm{m}$ apart, area: $5 \mathrm{~mm}^{2}$ ). For the determination of erosion, the nail polish was removed after the experiment. Then, five scans using a roughness tip were recorded at exactly the same sites as done at baseline. To achieve this outcome, the specimens presented identification marks (small drillings made with a $0.25-\mathrm{mm}$ drill head) and were inserted into a metal device to allow the stylus to be accurately repositioned at each measurement. Baseline and final profiles were carried out and compared using the software MarSurf CXR20. The scans were superposed and the average depth of the area under the curve was calculated (in micrometres).

Protective Effect of Fluoridated Milk against Dental Erosion

\section{Statistical Analysis}

The software GraphPad InStat (GraphPad Software, San Diego, Calif., USA) and StatSoft (Tulsa, Okla., USA) were used. The assumptions of equality of variance and normal distribution of data were checked for all the variables. The equality of variance was not satisfied, so the differences among all treatments were analysed using the Kruskal-Wallis test followed by Dunn's test for enamel and dentine, separately. The level of significance was set at $5 \%$.

\section{Results}

Tables 1 and 2 show enamel and dentine erosion results, respectively (Kruskal-Wallis and Dunn's tests). For enamel, the treatment with whole milk containing 10 ppm F, before the erosive challenge, led to the lowest val- 
Table 1. Median \pm interquartile range of enamel erosion after 5 days of $\mathrm{pH}$ cycling and treatment $(\mu \mathrm{m})$

\begin{tabular}{lll}
\hline Treatment of enamel & $\begin{array}{l}\text { After erosive } \\
\text { challenge }\end{array}$ & $\begin{array}{l}\text { Before erosive } \\
\text { challenge }\end{array}$ \\
\hline $0.9 \%$ NaCl solution & $1.98 \pm 0.71^{\mathrm{a}}$ & - \\
Whole milk with 0 ppm F & $1.96 \pm 0.64^{\mathrm{a}}$ & $1.67 \pm 0.32^{\mathrm{a}, \mathrm{b}}$ \\
Whole milk with 2.5 ppm F & $1.54 \pm 0.58^{\mathrm{a}-\mathrm{c}}$ & $1.38 \pm 0.66^{\mathrm{a}-\mathrm{c}}$ \\
Whole milk with 5 ppm F & $1.48 \pm 0.50^{\mathrm{a}-\mathrm{c}}$ & $1.53 \pm 0.45^{\mathrm{a}-\mathrm{c}}$ \\
Whole milk with 10 ppm F & $1.29 \pm 0.23^{\mathrm{b}, \mathrm{c}}$ & $0.98 \pm 0.25^{\mathrm{c}}$ \\
Fat-free milk with 0 ppm F & $1.77 \pm 1.18^{\mathrm{a}, \mathrm{b}}$ & $1.78 \pm 0.38^{\mathrm{a}, \mathrm{b}}$ \\
Fat-free milk with 2.5 ppm F & $1.68 \pm 0.21^{\mathrm{a}, \mathrm{b}}$ & $1.49 \pm 0.62^{\mathrm{b}, \mathrm{c}}$ \\
Fat-free milk with 5 ppm F & $1.41 \pm 0.39^{\mathrm{a}-\mathrm{c}}$ & $1.52 \pm 0.34^{\mathrm{a}-\mathrm{c}}$ \\
Fat-free milk with 10 ppm F & $1.70 \pm 0.49^{\mathrm{a}, \mathrm{b}}$ & $1.40 \pm 0.37^{\mathrm{a}-\mathrm{c}}$ \\
$0.05 \%$ NaF solution & $1.62 \pm 0.66^{\mathrm{a}-\mathrm{c}}$ & $1.54 \pm 0.61^{\mathrm{a}-\mathrm{c}}$ \\
\hline
\end{tabular}

Superscript letters indicate significant differences among the treatments. Kruskal-Wallis test followed by Dunn's test $(\mathrm{p}<0.05)$.

Table 2. Median \pm interquartile range of dentine erosion after 5 days of $\mathrm{pH}$ cycling and treatment $(\mu \mathrm{m})$

\begin{tabular}{lll}
\hline Treatment of dentine & $\begin{array}{l}\text { After erosive } \\
\text { challenge }\end{array}$ & $\begin{array}{l}\text { Before erosive } \\
\text { challenge }\end{array}$ \\
\hline $0.9 \%$ NaCl solution & $2.92 \pm 0.39^{\mathrm{a}, \mathrm{b}}$ & - \\
Whole milk with 0 ppm F & $3.40 \pm 0.73^{\mathrm{a}}$ & $2.04 \pm 0.54^{\mathrm{c}-\mathrm{f}}$ \\
Whole milk with 2.5 ppm F & $2.09 \pm 0.46^{\mathrm{c}-\mathrm{f}}$ & $2.38 \pm 0.31^{\mathrm{a}-\mathrm{e}}$ \\
Whole milk with 5 ppm F & $2.03 \pm 0.36^{\mathrm{c}-\mathrm{g}}$ & $1.96 \pm 0.34^{\mathrm{c}-\mathrm{g}}$ \\
Whole milk with 10 ppm F & $1.83 \pm 0.17^{\mathrm{d}-\mathrm{g}}$ & $1.66 \pm 0.54^{\mathrm{d}-\mathrm{g}}$ \\
Fat-free milk with 0 ppm F & $2.75 \pm 0.52^{\mathrm{a}-\mathrm{c}}$ & $2.58 \pm 0.24^{\mathrm{a}-\mathrm{d}}$ \\
Fat-free milk with 2.5 ppm F & $1.98 \pm 0.55^{\mathrm{b}-\mathrm{f}}$ & $2.64 \pm 0.17^{\mathrm{a}-\mathrm{c}}$ \\
Fat-free milk with 5 ppm F & $1.88 \pm 0.74^{\mathrm{a}-\mathrm{g}}$ & $2.25 \pm 0.36^{\mathrm{a}-\mathrm{e}}$ \\
Fat-free milk with 10 ppm F & $1.95 \pm 0.44^{\mathrm{c}-\mathrm{g}}$ & $1.73 \pm 0.34^{\mathrm{e}-\mathrm{g}}$ \\
0.05\% NaF solution & $1.44 \pm 0.31^{\mathrm{f}, \mathrm{g}}$ & $1.17 \pm 0.17^{\mathrm{g}}$ \\
\end{tabular}

Superscript letters indicate significant differences among the treatments. Kruskal-Wallis test followed by Dunn's test $(\mathrm{p}<0.05)$.

ues compared with the negative control, but with no significant difference compared with the same treatment carried out after the erosive challenge. The other treatments did not differ from each other or from the negative control, except for the group treated with fat-free milk containing $2.5 \mathrm{ppm} F$ before the erosive challenge, which performed significantly better than the negative control.

For dentine, the addition of $\mathrm{F}$ to the milk had a better protective effect against erosion compared with enamel. Groups treated with whole milk containing 2.5, 5.0 and $10 \mathrm{ppm}$ F, before or after the erosive challenge, were significantly different from the negative control (except for the group treated with $2.5 \mathrm{ppm} F$ before the erosive challenge), but they did not differ from each other. Whole milk without $\mathrm{F}$ applied before the erosive challenge, fatfree milk with $10 \mathrm{ppm} \mathrm{F}$ and the positive control (both before and after the erosive challenge) also showed significant difference compared with the negative control. The application of milk before the erosive challenge was more effective in reducing dentine erosion compared with the application after erosive challenge, but only in the absence of $\mathrm{F}$.

\section{Discussion}

Clinical studies involving the ingestion of fluoridated milk began in the 1950s in Japan, USA and Switzerland. The results showed an increase in the percentage of caries-free dentitions in school-aged children treated with fluoridated milk compared with the control groups [Ziegler, 1953; Imamura, 1959; Rusoff et al., 1962; Stephen et al., 1984; Yeung et al., 2005]. Since then, in different regions where water fluoridation was not feasible due to political, technical or geographical reasons [Sampaio and Levy, 2011], milk fluoridation schemes started (0.5$1.0 \mathrm{mg} /$ day) through school-based preventive programmes [Banoczy et al., 2013] in order to prevent the occurrence of carious lesions.

As a positive result of oral health prevention programmes, either through the ingestion of $\mathrm{F}$ from water, milk or the application of dental products, people started to retain their teeth in the mouth for a longer time compared with the past [Arnold et al., 2014]. Furthermore, with the advent of the industrialisation process and changes in lifestyle and eating habits, other oral diseases have become more common, such as, for example, tooth erosion.

Tooth erosion is a loss of structure caused by extrinsic or intrinsic acids capable of promoting the dissolution of the minerals [Lussi, 2006]. Thus, it would be interesting to observe the effect of fluoridated milk in the erosion process, due to the possibility of forming a physical barrier, rich in lipids, proteins and also F, capable of protecting enamel and dentine against the erosive dissolution process and of facilitating some remineralisation.

The $\mathrm{F}$ concentrations in milk tested in studies involving dental caries range from 0.25 to $10.0 \mathrm{ppm}$ [Giacaman et al., 2012; Malinowski et al., 2012b; Arnold et al., 2014; Lippert et al., 2014; Ongtenco et al., 2014]. In this study, the lowest concentration used was $2.5 \mathrm{ppm} F$ due to the fact that the erosive process is more aggressive than the 
cariogenic challenge. Therefore, $\mathrm{F}$ concentrations lower than $2.5 \mathrm{ppm}$ would probably not have any effect on the prevention of erosion. We should also consider that $\mathrm{F}$ has a preventive effect only in the free form. When added to milk, F can interact with calcium ions or proteins, so that only part of the added $\mathrm{F}$ would be free to protect against the erosion process.

Wiegand and Attin [2014] did not find any protective effect of whole milk (with or without $5.0 \mathrm{ppm} \mathrm{F}$ ) against enamel and dentine erosion and abrasion in situ. In the present study, whole milk with 5.0 ppm F (applied after the erosive challenge, as done by the former authors) was able to reduce dentine erosion only. Our protocol could have facilitated the effect of fluoridated milk as we did not have further abrasive challenges that increase erosion, nor was there exposure to human saliva, which is rich in proteins that could also have some protective effect against erosion, thus minimising the effect of milk.

Another previous study demonstrated a beneficial effect of applying milk before an erosive challenge both to enamel and dentine, with the best effect found for dentine [Magalhães et al., 2014]. In addition, all F concentrations $(2.5,5.0$ and $10.0 \mathrm{ppm} F)$ had a positive effect on the prevention of enamel and dentine erosion when milk was applied after the erosive challenge. The F solution (NaF) showed a better effect on dentine than on enamel, in agreement with the present results.

Similarly to Magalhães et al. [2014], the present results also showed a beneficial effect of milk before the erosive challenge, especially for enamel (for dentine, only in the absence of F), which might be due to the protein content rather than fat, since there was no significant difference between whole and fat-free milk (table 1). Milk casein has already been shown to have some protective effect against tooth erosion [Cheaib and Lussi, 2011; Nongonierma and Fitzgerald, 2012].

In the present study, we were able to see a beneficial effect for dentine for all $\mathrm{F}$ concentrations when whole milk was used after the erosive challenge and for 5 and $10 \mathrm{ppm}$ $\mathrm{F}$ when the milk was applied before the erosive challenge. However, for fat-free milk, only the highest F concentration was effective, regardless of the time of application. These results have some implications. First, in the absence of fat, it is necessary to have at least $10 \mathrm{ppm} \mathrm{F}$ to protect dentine against erosion. Second, in dentine, the protective effect of whole fluoridated milk seems to be more pronounced in the presence of the demineralised organic matrix, since a protective effect was achieved for all $\mathrm{F}$ concentrations when milk was applied after the erosive challenge. These findings need to be confirmed, but in principle they indicate that $\mathrm{F}$ works more in dentine remineralisation than in the prevention of dentine demineralisation and that fat might act synergistically with F. In fact, the effects of $F$ in the reduction of dentine erosion seem to be dependent on the presence of the demineralised organic matrix [Ganss et al., 2010], which might be attributed to the inhibitory effect of $\mathrm{F}$ on the activity of matrix metalloproteinases [Kato et al., 2014]. It might also be possible that $F$ interferes in the formation of a fat barrier on dentine when both components are present in milk.

However, for enamel, whole milk with 10 ppm F (regardless of the time of application) was effective, also suggesting a synergistic effect between $\mathrm{F}$ and fat, with the latter probably acting as a physical barrier to protect against the acids. These results were different from those reported in our previous study [Magalhães et al., 2014]. The hypothesis to explain such differences between both studies is the fact that in the present study we had 19 treatments, a larger number of groups than in our previous work [Magalhães et al., 2014], reducing the probability of finding significant differences among them. Based on the results, we showed no dose-response effect in the present study and $10 \mathrm{ppm} F$ seems to be the most effective F concentration against both enamel and dentine erosion. In milk fluoridation schemes worldwide, the amount of fluoride added to milk usually ranges between 0.5 and 1.0 $\mathrm{mg}$ per day [Banoczy et al., 2013]. Since a glass containing $200 \mathrm{ml}$ of milk is offered daily to the children, the F concentration in milk typically ranges between 2.5 and 5.0 ppm. Considering that erosive challenges are more aggressive than cariogenic challenges, we decided to include in the present study a treatment with $10 \mathrm{ppm} F$ milk. This concentration might be high for children at the age of risk to dental fluorosis (up to 6 years) [Buzalaf and Levy, 2011] but could be employed to prevent erosion in older children, adolescents or adults.

Therefore, we can speculate that, among the studied factors, the most important one to reduce dental erosion is the presence of $F(10 \mathrm{ppm} \mathrm{F})$. In general, the effects of fat and the time of application are modulated by the presence of F. Thus, all null hypotheses were rejected, since all studied factors interfered in the erosion of enamel and dentine.

\section{Acknowledgements}

This study was supported by The Borrow Foundation. The authors thank FAPESP for the concession of a PhD scholarship to the first author (Process No. 2014/22430-0). 


\section{Author Contributions}

M.A.R.B., A.C.M. and J.P.P. conceived and designed the study. L.P.S.C., S.C., J.G.S. and L.C.L. performed the experiments. L.P.S.C., S.C., M.A.R.B. and A.C.M. analysed the data. The manuscript was drafted by L.P.S.C., A.C.M. and M.A.R.B. All authors read the manuscript.

\section{Disclosure Statement}

The authors declare no conflicts of interest.

\section{References}

Aimutis WR: Bioactive properties of milk proteins with particular focus on anticariogenesis. J Nutr 2004;134:989S-995S.

Arnold WH, Heidt BA, Kuntz S, Naumova EA: Effects of fluoridated milk on root dentin remineralization. PLoS One 2014;9:e104327.

Banoczy J, Rugg-Gunn A, Woodward M: Milk fluoridation for the prevention of dental caries. Acta Med Acad 2013;42:156-167.

Buzalaf MA, Levy SM: Fluoride intake of children: considerations for dental caries and dental fluorosis. Monogr Oral Sci 2011;22:1-19.

Buzalaf MA, Hannas AR, Kato MT: Saliva and dental erosion. J Appl Oral Sci 2012;20:493502.

Cheaib Z, Lussi A: Impact of acquired enamel pellicle modification on initial dental erosion. Caries Res 2011;45:107-112.

Ganss C, Klimek J, Starck C: Quantitative analysis of the impact of the organic matrix on the fluoride effect on erosion progression in human dentine using longitudinal microradiography. Arch Oral Biol 2004;49:931-935.

Ganss C, Lussi A, Sommer N, Klimek J, Schlueter $\mathrm{N}$ : Efficacy of fluoride compounds and stannous chloride as erosion inhibitors in dentine. Caries Res 2010;44:248-252.

Gedalia I, Dakuar A, Shapira L, Lewinstein I, Goultschin J, Rahamim E: Enamel softening with Coca-Cola and rehardening with milk or saliva. Am J Dent 1991a;4:120-122.

Gedalia I, Ionat-Bendat D, Ben-Mosheh S, Shapira L: Tooth enamel softening with a cola type drink and rehardening with hard cheese or stimulated saliva in situ. J Oral Rehabil 1991b;18:501-506.

Giacaman RA, Munoz MJ, Ccahuana-Vasquez RA, Munoz-Sandoval C, Cury JA: Effect of fluoridated milk on enamel and root dentin demineralization evaluated by a biofilm caries model. Caries Res 2012;46:460-466.

Imamura Y: Treatment of school meals with sodium fluoride as a means of preventing tooth decay. J Oral Dis Acad 1959;26:180-199.
Kato M, Bolanho B, Zarella B, Salo T, Tjäderhane L, Buzalaf M: Sodium fluoride inhibits MMP2 and MMP-9. J Dent Res 2014;93:74-77.

Klimek J, Hellwig E, Ahrens G: Fluoride taken up by plaque, by the underlying enamel and by clean enamel from three fluoride compounds in vitro. Caries Res 1982;16:156-161.

Li H, Zou Y, Ding G: Dietary factors associated with dental erosion: a meta-analysis. PLoS One 2012; 7:e42626.

Lippert F, Martinez-Mier EA, Zero DT: An in situ caries study on the interplay between fluoride dose and concentration in milk. J Dent 2014; 42:883-890.

Lussi A: Erosive tooth wear - a multifactorial condition of growing concern and increasing knowledge. Monogr Oral Sci 2006;20:1-8.

Magalhães AC, Levy FM, Souza BM, Cardoso CA, Cassiano LP, Pessan JP, Buzalaf MA: Inhibition of tooth erosion by milk containing different fluoride concentrations: an in vitro study. J Dent 2014;42:498-502.

Malinowski M, Duggal MS, Strafford SM, Toumba KJ: The effect of varying concentrations of fluoridated milk on enamel remineralisation in vitro. Caries Res 2012a;46:555-560.

Malinowski M, Duggal MS, Strafford SM, Toumba KJ: The effect on dental enamel of varying concentrations of fluoridated milk with a cariogenic challenge in situ. J Dent 2012b;40: 929-933.

Manaf ZA, Lee MT, Ali NH, Samynathan S, Jie YP, Ismail NH, Bibiana Hui Ying Y, Wei Seng Y, Yahya NA: Relationship between food habits and tooth erosion occurrence in Malaysian university students. Malays J Med Sci 2012;19: 56-66.

Merritt J, Qi F, Shi W: Milk helps build strong teeth and promotes oral health. J Calif Dent Assoc 2006;34:361-366.

Nahas Pires Correa MS, Nahas Pires Correa F, Nahas Pires Correa JP, Murakami C, Mendes FM: Prevalence and associated factors of dental erosion in children and adolescents of a private dental practice. Int J Paediatr Dent 2011;21:451-458
Nongonierma AB, Fitzgerald RJ: Biofunctional properties of caseinophosphopeptides in the oral cavity. Caries Res 2012;46:234-267.

Ongtenco KL, Anthonappa RP, Itthagarun A, King NM, Lalloo R, Nair RG: Remineralization of initial enamel carious lesions using fluoridated milk in vitro. Acta Odontol Scand 2014;72:737-744.

Rugg-Gunn AJ: Nutrition, diet and dental public health. Community Dent Health 1993; 10(suppl 2):47-56.

Rusoff LL, Konikoff BS, Frye JB Jr, Johnston JE, Frye WW: Fluoride addition to milk and its effect on dental caries in school children. Am J Clin Nutr 1962;11:94-101.

Salas MM, Nascimento GG, Vargas-Ferreira F, Tarquinio SB, Huysmans MC, Demarco FF: Diet influenced tooth erosion prevalence in children and adolescents: results of a metaanalysis and meta-regression. J Dent 2015;43: 865-875.

Sampaio FC, Levy SM: Systemic fluoride. Monogr Oral Sci 2011;22:133-145.

Stephen KW, Boyle IT, Campbell D, McNee S, Boyle P: Five-year double-blind fluoridated milk study in Scotland. Community Dent Oral Epidemiol 1984;12:223-229.

Wiegand A, Attin T: Randomised in situ trial on the effect of milk and CPP-ACP on dental erosion. J Dent 2014;42:1210-1215.

Wiegand A, Bliggenstorfer S, Magalhães AC, Sener B, Attin T: Impact of the in situ formed salivary pellicle on enamel and dentine erosion induced by different acids. Acta Odontol Scand 2008;66:225-230.

Yeung CA, Hitchings JL, Macfarlane TV, Threlfall AG, Tickle M, Glenny AM: Fluoridated milk for preventing dental caries. Cochrane Database Syst Rev 2005;3:CD003876.

Ziegler E: Milk fluorination in prophylaxis of dental caries. Schweiz Med Wochenschr 1953;83:723-724. 